\title{
Correction
}

\section{Correction: Widespread Use and Frequent Detection of Neonicotinoid Insecticides in Wetlands of Canada's Prairie Pothole Region}

\section{The PLOS ONE Staff}

There is an error in the third to last sentence of the Abstract. The neonicotinoid concentration units should be listed as $\mu \mathrm{g} / \mathrm{kg}$ rather than $\mathrm{ng} / \mathrm{L}$. The correct sentence is:

"Sediment samples collected during the same period rarely $(6 \%)$ contained neonicotinoid concentrations (which did not exceed 20 $\mu \mathrm{g} / \mathrm{kg})$."

\section{Reference}

1. Main AR, Headley JV, Peru KM, Michel NL, Cessna AJ, et al. (2014) Widespread Use and Frequent Detection of Neonicotinoid Insecticides in Wetlands of Canada's Prairie Pothole Region. PLoS ONE 9(3): e92821. doi:10.1371/journal.pone.0092821
Citation: The PLOS ONE Staff (2014) Correction: Widespread Use and Frequent Detection of Neonicotinoid Insecticides in Wetlands of Canada's Prairie Pothole Region. PLoS ONE 9(6): e101400. doi:10.1371/journal.pone.0101400

Published June 24, 2014

Copyright: (c) 2014 The PLOS ONE Staff. This is an open-access article distributed under the terms of the Creative Commons Attribution License, which permits unrestricted use, distribution, and reproduction in any medium, provided the original author and source are credited. 